\title{
HUBUNGAN KECERDASAN EMOSIONAL TERHADAP HASIL BELAJAR SISWA
}

\author{
Budi Mulyati ${ }^{1}$, Elfaumi Farkhah ${ }^{2}$ \\ Universitas Banten Jaya \\ Serang, Indonesia \\ budimulyati@unbaja.ac.id ${ }^{1}$, elfaumifarkhah@unbaja.ac.id ${ }^{2}$
}

\begin{abstract}
The aim of this study was to determine the relationship between emotional intelligence and student learning result in SMKN 1 Ciruas. The method was quantitative method and took place in SMKN 1 Ciruas. The subject on this study were all accounting students as many as 113 students. The data of learning result was obtained by using teacher assessment and the questionnaire sheet was used to got students' responses. This study used quantitative data analysis technique. The result showed that there was a positive relationship between emotional intelligence and students learning result. It was known from the data analysis that $r_{\text {test }}(0.701)>r_{\text {table }}(0.184)$.
\end{abstract}

\section{Keywords: Emotional intelligence, Learning Result}

\section{PENDAHULUAN}

Hasil belajar peserta didik dijadikan salah satu indikator keberhasilan suatu proses pembelajaran di sekolah, bahkan dapat pula digunakan sebagai salah satu penanda tinggi atau rendahnya mutu pendidikan yang dimiliki oleh suatu masyarakat. Salah satu alasan yang melatarbelakanginya adalah hasil belajar peserta didik dapat dijadikan oleh masyarakat untuk menunjukan kemampuan yang dimiliki oleh peserta didik dalam hal penguasaan suatu pengetahuan atau keterampilan tertentu yang telah dipelajarinya di sekolah.
Menurut Syah (2018:144) terdapat dua faktor yang dapat memengaruhi hasil belajar peserta didik, yakni faktor internal dari diri peserta didik serta faktor eksternal yang berasal dari luar diri peserta didik.Beberapa faktor internal yang dapat memengaruhi hasil belajar peserta didik diantaranya kesehatan, intelegensia, perhatian, sikap, minat, bakat, motivasi, kelelahan dan disiplin belajar.Sedangkan factor eksternal yang dapat memengaruhi hasil belajar peserta didik diantaranya pola asuh orang tua, hubungan diantara anggota keluarga, latar belakang budaya, metode mengajar, media pelajaran, kurikulum, 
PROGRESS

Jurnal Pendid ikan, Akuntansi dan Keuangan

Universitas Banten Jaya
Vol 3 No. 1, Februari 2020

E-ISSN 2622-7037 |P-ISSN 2623-0763 hubungan peserta didik dengan teman sebayanya serta kegiatan peserta didik yang dilakukan di masyarakat.

Potensi yang dimiliki peserta didik tersebut dapat dioptimalkan sebagai upaya untuk meningkatkan kualitas sumber daya manusia. Peningkatan kualitas sumber daya manusia ini tidak terlepas dari harapan bahwa masyarakat Indonesia memiliki kemampuan sehingga dapat bersaing dengan masayarakat dari wilayah lain. Namun demikian peningkatan sumber daya manusia harus diarahkan pada peningkatan kompetensi sumber daya manusia yang juga memiliki kecerdasan emosional dan spiritual keagamaan.

Kecerdasan emosional dan spiritual keagamaan ini sangat penting karena dengan kecerdasan emosional dan spiritual kegamaan yang baik akan membuat masyarakat memiliki ketahanan mental yang baik dalam menghadapi persaingan dengan masyarakat lainnya.Seseorang yang memiliki kecerdasan emosional yang baik memiliki kesadaran dan dorongan kendali hati, ketekunan, semnagat dan motivasi diri, empati serta memiliki kecakapan sosial.

Kecerdasan emosional dapat dimaknai sebagai kompetensi seseorang untuk dalam mengelola, menjaga keselarasan dan pengungakapan emosi secara sadar disertai dengan pengandalian dan motivasi diri, empati serta keterampilan sosial.Seseorang yang memiliki kecerdasan emosi akan mampu mengenali jati dirinya, mengendalikan dirinya, memotivasi dirinya, memiliki empati di lingkungan sekitar serta memiliki keterampilan sosial. Hal ini sesuai dengan karakter yang dinilai baik oleh masyarakat sehingga seseorang yang memiliki kecerdasan emosional yang baik akan dapat bersosialisasi dengan baik di masayarakat.

Goleman (2018:58) membagi kecerdasan emosional menjadi limakomponen yakni pengenalan diri, pengendalian dan motivasi sebagai bagian dari kompetensi emosional, kemudian terdapat komponen empati dan keterampilan sosial sebagai kompetensi sosial. Sedangkan Chandra (2014:41) menyebutkan bahwa fokus keefektifan emosional dan sosial mencakup menghargai diri sendiri, menghargai orang lain, memiliki kesadaran responsif, dan memiliki keberanian.

Kecerdasan emosional merupakan salah satu bentuk kompetensi seseorang untuk dapat memahami perasaan diri sendiri sehingga emosi dan intelektualnya dapat berkembang dengan baik.Sebagai bagian 
PROGRESS

Jurnal Pendidikan, Akuntansi dan Keuangan

Universitas Banten Jaya
Vol 3 No. 1, Februari 2020

E-ISSN 2622-7037 |P-ISSN 2623-0763 yang utuh dalam diri setiap individu, kecerdasan emosional memiliki peran yang sangat penting bagi seseorang dalam kehidupannya, terutama pada saat seorang individu belajar. Kecerdasan emosional yang dimilliki akan ikut berperan dalam membentuk kecerdasan yang lainnya, terutama kecerdasan intelektualnya. Dengan kecerdasan emosional yang baik maka seseorang dapat secara sadar memahami tentang makna dan urgensi belajar. Sehingga secara sadar seseorang secara alamiah akan berupaya secara optimal untuk dapat berhasil dalam belajarnya.

Hasil belajar berupa keberhasilan dalam domain kognitif, afektif dan psikomotor (Bloom dalam Suprijono, 2017:6).Walaupun terbagi menjadi tiga domain, namun ketiganya tidak dapat terpisahkan satu dengan yang lainnya.Hal tersebut dikarenakan bahwa hasil belajar tidak sebatas pada nilai yang merupakan ciri khas dari hasil belajar dalam domain kognitif, akan tetapi hasil belajar dapat pula dalam bentuk berupa perubahan sikap, kebiasaaan dan keterampilan.

Proses belajar seseorang dikatakan berhasil jika ketiga domain hasil belajar berhasil dikuasai dengan baik. Menurut Ibay
Toyyibah (2017:28) hasil belajar diklasifikasikan menjadi tiga, diantaranya:

1. Effectiveness

Efektifitas pembelajaran diukur dengan tingkat pencapaian peserta didik diantaranya tingkat kecermatan, kecepatan unjuk kerja, tingkat ahli belajar serta tingkat retensi dari apa yang dipelajari.

\section{Efficiency}

Efisiensi pembelajaran dapat dinilai berdasarkan dari efektifitas belajar dan waktu yang dipakai serta jumlah biaya yang telah digunakan.

\section{Appeal}

Daya tarik pembelajaran diukur dengan mengamati kecenderungan seseorang untuk tetap belajar.

\section{METODE PENELITIAN}

Penelitian ini menggunakan metode penelitian korelasional karena penelitian ini dilakukan untuk mengetahui pengaruh diantara variabel bebas yakni variabel kecerdasan emosional dan variabel terikat yakni variabel hasil belajar. Penelitian ini dilakukan di SMK Negeri Ciruas 1 Serang dengan subjek penelitian sebanyak 113 peserta didik jurusan Akuntansi yang terdiri dari kelas X (36 peserta didik), kelas XI (34 
PROGRESS

Jurnal Pendid ikan, Akuntansi dan Keuangan

Universitas Banten Jaya
Vol 3 No. 1, Februari 2020

E-ISSN 2622-7037 |P-ISSN 2623-0763 peserta didik) dan kelas XII (43 peserta didik.

Data yang diperoleh dalam penelitian ini menggunakan teknik penelitian berupa angket dan dokumentasi.Teknik angket digunakan untuk mengetahui respon peserta didik tentang kecerdasan emosional. Adapun operasionalisasi variabel untuk kecerdasan emosional dapat dilihat di tabel 1 berikut ini;

Tabel 1. Operasionalisasi Variabel Kecerdasan Emosional

\begin{tabular}{|c|c|c|c|}
\hline No & Aspek & Indikator & Deskriptor \\
\hline \multirow[t]{7}{*}{1} & \multirow{7}{*}{$\begin{array}{l}\text { Kecakapan } \\
\text { pribadi }\end{array}$} & \multirow{2}{*}{$\begin{array}{l}\text { Kesadaran } \\
\text { diri }\end{array}$} & Kesadaran emosi \\
\hline & & & $\begin{array}{l}\text { Penilaian diri } \\
\text { secara teliti }\end{array}$ \\
\hline & & \multirow{2}{*}{$\begin{array}{l}\text { Pengaturan } \\
\text { diri }\end{array}$} & Kendali diri \\
\hline & & & $\begin{array}{ll}\text { Sifat dapat } \\
\text { dipercaya } \\
\text { Inovasi }\end{array}$ \\
\hline & & \multirow[t]{3}{*}{ Motivasi } & $\begin{array}{l}\text { Dorongan } \\
\text { prestasi }\end{array}$ \\
\hline & & & Komitmen \\
\hline & & & Optimisme \\
\hline \multirow[t]{8}{*}{2} & \multirow[t]{8}{*}{$\begin{array}{l}\text { Kecakapan } \\
\text { sosial }\end{array}$} & \multirow[t]{4}{*}{ Empati } & $\begin{array}{l}\text { Memahami } \\
\text { orang lain }\end{array}$ \\
\hline & & & Mengatasi \\
\hline & & & keberagaman \\
\hline & & & $\begin{array}{l}\text { Mengembangkan } \\
\text { orang lain }\end{array}$ \\
\hline & & \multirow{4}{*}{$\begin{array}{l}\text { Keterampilan } \\
\text { sosial }\end{array}$} & Pengaruh \\
\hline & & & Manajemen \\
\hline & & & konflik \\
\hline & & & $\begin{array}{l}\text { Pengikat } \\
\text { jaringan }\end{array}$ \\
\hline
\end{tabular}

Sumber: Goleman, 2018: 58-59

Data yang diperoleh dengan menggunakan teknik dokumentasi yakni data berupa hasil belajar yang diperoleh dari penilaian tengah semester di semester genap tahun ajaran 2018/2019 berupa angka dalam rentang 10-100. Data ini peneliti peroleh dari masing-masing guru wali kelas jurusan Akuntansi mulai dari kelas X, XI dan XII.

Data yang diperoleh dianalisis dengan menggunakan teknik analisis kuantitatif.

\section{HASIL PENELITIAN DAN PEMBAHASAN}

\section{Deskripsi Data Kecerdasan Emosional}

Respon kecerdasan emosional diperoleh melalui pemberian angket kepada 113 peserta didik.Angket yang diberikan terdiri dari tiga puluh butir pernyataan dengan menggunakan skala likert 1-4.Angket yang telah diisi kemudian dianalisis menggunakan SPSS.Hasil statistik deskriptif menunjukkan bahwa dari 113 responden, skor terendah sebesar 89 dan skor tertinggi sebesar 115 . Adapun rerata skor sebesar 103,14 dengan nilai standar deviasi sebesar 5,998.

Berdasarkan hasil statistik deskriptif, selanjutnya disajikan perolehan skor masing- masing responden ke dalam kelas interval tertentu. Banyaknya kelas yang diperlukan dapat diketahui dengan menggunakan rumus $1+3,3 \log \mathrm{n}$. Dengan jumlah responden sebanyak 113, diperoleh hasil bahwa banyaknya kelas yang diperlukan sebanyak 7,7 atau dapat dibulatkan menjadi 8 kelas. 
PROGRESS

Jurnal Pendidikan, Akuntansi dan Keuangan Universitas Banten Jaya
Vol 3 No. 1, Februari 2020

E-ISSN 2622-7037 |P-ISSN 2623-0763

Tabel 2. Distribusi Frekuensi Skor Kecerdasan Emosional

\begin{tabular}{ccc}
\hline Interval & Frekuensi & Persentase \\
\hline $89,0-91,5$ & 3 & $3 \%$ \\
$92,5-95,0$ & 8 & $8 \%$ \\
$96,0-98,5$ & 13 & $12 \%$ \\
$99,5-102,0$ & 24 & $21 \%$ \\
$103,0-105,5$ & 26 & $23 \%$ \\
$106,5-109,0$ & 19 & $17 \%$ \\
$110,0-112,5$ & 15 & $13 \%$ \\
$113,5-117,0$ & 5 & $4 \%$ \\
\hline
\end{tabular}

Sumber: Data diolah

Berdasarkan tabel tersebut diketahui bahwa frekuensi rentang skor paling banyak berada pada kelas 103,0 - 105,5 (23\%). Sedangkan skor dengan frekuensi paling rendah berada dalam kelas 89,0 - 91,5 (3\%).

Selanjutnya

dilakukan

pengkategorian data kecerdasan emosional.Hal ini dilakukan dengan tujuan untuk mengetahui kategori tingkat kecerdasan emosional peserta didik jurusan Akuntansi di SMK Negeri 1 Ciruas.

Terdapat tiga kategori hasil belajar yakni rendah, sedang dan tinggi. Penentuan kategori hasil belajar dapat dilihat dalam tabel berikut ini;

\section{Tabel 3. Kategorisasi Ideal Skor Data}

\begin{tabular}{ll}
\hline Tinggi & $X \geq(\mu+\sigma)$ \\
Sedang & $(\mu-\sigma) \leq X<(\mu+\sigma)$ \\
Rendah & $X<(\mu-\sigma)$ \\
\hline
\end{tabular}

Berdasarkan hasil perhitungan dengan menggunakan kategorisasi ideal skor data, diperoleh hasil sebagai berikut;

Tabel 4. Kategorisasi Kecerdasan Emosional

\begin{tabular}{|c|c|c|c|c|}
\hline \multirow{2}{*}{$\begin{array}{l}\text { Kategori } \\
\text { Tinggi }\end{array}$} & \multicolumn{2}{|c|}{ Rumus } & \multicolumn{2}{|c|}{ Batasan } \\
\hline & $\mathrm{X} \geq(\mu+\sigma)$ & & $X \geq 109$ & $109-120$ \\
\hline Sedang & $(\mu-\sigma) \leq X$ & $\Lambda+\sigma)$ & $97 \leq X<109$ & $97-108$ \\
\hline Rendah & $X<(\mu-\sigma)$ & & $X<97$ & $30-96$ \\
\hline \multicolumn{2}{|c|}{ Skor Maksimal $=120$} & $\mu=1$ & & \\
\hline \multicolumn{2}{|c|}{ Skor Minimal $=30$} & $\sigma=6$ & & \\
\hline
\end{tabular}

Sumber: Data diolah

Tabel tersebut memperlihatkan bahwa skor tertinggi ideal berada pada rentang 109-120.Skor ideal sedang berada pada rentang 97-108 sedangkan skor ideal paling rendah berada dalam rentang 30-96.

Banyaknya jumlah peserta didik yang ada dalam setiap kategori dapat digambarkan dalam diagram berikut ini;

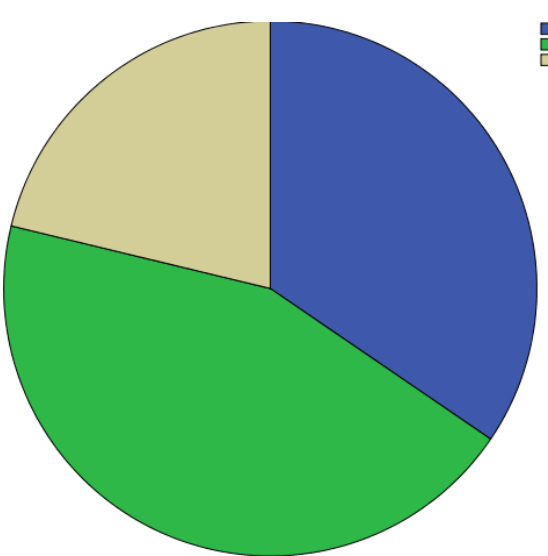

Gambar Diagram Pie kategorisasi kecerdasan Emosional

Sumber: Data diolah

Di dalam diagram tersebut terlihat bahwa sebagian besar (44\%) berada dalam kategori sedang. Sedangkan $21,2 \%$ berada 
PROGRESS

Jurnal Pendid ikan, Akuntansi dan Keuangan

Universitas Banten Jaya
Vol 3 No. 1, Februari 2020

E-ISSN 2622-7037 |P-ISSN 2623-0763 dalam kategori tinggi dan $34,5 \%$ berada dalam kategori rendah.

\section{Deskripsi Data Hasil Belajar}

Data hasil belajar yang digunakan yakni berasal dari penilaian tengah semester peserta didik.Berikut ini disajikan hasil analisis data deskriptif statistiknya.

Tabel. 5 Deskripsi Hasil Belajar

\begin{tabular}{llllllll}
\hline & $\mathrm{N}$ & Range & Min & Max & Sum & Mean & \\
\cline { 2 - 8 } & Statistic & Statistic & Statistic & Statistic & Statistic & Statistic & Std. \\
$\begin{array}{l}\text { Hasil_ } \\
\text { belajar }\end{array}$ & 113 & 18 & 75 & 93 & 9625 & 85,18 &, 351 \\
$\begin{array}{l}\text { Valid } N \\
\text { (listwise) }\end{array}$ & 113 & & & & & & \\
\hline \multicolumn{2}{l}{ Sumber: Data Diolah } & & & & & &
\end{tabular}

Berdasarkan tabel tersebut secara umum dapat diketahui bahwa skor tertinggi dari hasil penilaian tengah semester yang diperoleh sebesar 93 sedangkan skor terrendahnya sebesar Rp 75. Adapun ratarata skor hasil belajar yang diperoleh sebesar 85,18 dengan standar deviasi sebesar 3,735. Dan adapun berdasarkan hasil analisis perolehan skor setiap peserta didik, diperoleh persentase setiap rentang hasil belajar sebagai berikut;

Tabel. 6. Persentase rentang hasil belajar

\begin{tabular}{lcc}
\hline Interval & Frekuensi & Persentase \\
\hline $75,0-76,5$ & 3 & $3 \%$ \\
$77,5-79,5$ & 3 & $3 \%$ \\
$80,0-81,5$ & 9 & $8 \%$ \\
$82,5-84,0$ & 30 & $26 \%$ \\
$85,0-86,5$ & 25 & $22 \%$ \\
$87,5-89,0$ & 30 & $27 \%$ \\
$90,0-915$ & 9 & $8 \%$ \\
$92,5-94,0$ & 4 & $3 \%$ \\
Total & 113 & $100 \%$ \\
\hline
\end{tabular}

Sumber: Data Diolah

Berdasarkan tabel tersebut diketahui bahwa perolehan nilai/skor paling banyak berada pada rentang 82,5 - 84,0 serta di rentang 87,5 - 89,0. Adapun perolehan skor yang tertinggi berada di rentang skor 92,5 94,0 yang didapatkan oleh 4 orang peserta didik. Sedangkan rentang skor paling rendah berada dalam rentang skor 75,0 - 76,5 Std

3,735 Penentuan kategorisasi hasil belajar dideskripsikan dengan tujuan untuk menunjukkan kategori hasil belajar peserta didik jurusan Akuntansi di SMK Negeri 1 Ciruas.Berdasarkan data hasil belajar yang diperoleh, kategorisasi hasil belajar peserta didik dapat dilihat di tabel berikut ini;

Tabel 7. Kategori Tingkat Hasil Belajar Peserta Didik Jurusan Akuntansi

\begin{tabular}{lllc}
\hline Kategori & \multicolumn{1}{c}{ Rumus } & \multicolumn{2}{c}{ Batasan } \\
\hline Tinggi & $X \geq(\mu+\sigma)$ & $X \geq 89$ & $89-100$ \\
Sedang & $(\mu-\sigma) \leq X$ & $81 \leq X<81-88$ \\
& $<(\mu+\sigma)$ & 89 & \\
Rendah & $X<(\mu-\sigma)$ & $X<81$ & $75-80$ \\
\hline Skor Maksimal $=100$ & $\mu=85$ & \\
Skor Minimal $=75$ & $\sigma=4$ & \\
\hline Sumber: Data Diolah &
\end{tabular}

Berdasarkan tabel tersebut diketahui bahwa interval skor tertinggi berada pada nilai 89 - 100.Interval skor sedang berada pada nilai 81 - 88 sedangkan interval skor rendah berada pada rentang skor $75-80$. 
PROGRESS

Jurnal Pendid ikan, Akuntansi dan Keuangan Universitas Banten Jaya
Vol 3 No. 1, Februari 2020

E-ISSN 2622-7037 |P-ISSN 2623-0763
Dengan bantuan SPSS, frekuensi danpersentasi peserta didik yang berada di dalam masing- masing rentang kategori perolehan skor hasil belajar dapat dilihat dalam tabel berikut ini;

Tabel 8. Kategorisasi Hasil Belajar Peserta Didik Jurusan Akuntansi

\begin{tabular}{llll}
\hline & & Frequency & Percent \\
\hline Valid & Rendah & 15 & 13,3 \\
& Sedang & 76 & 67,3 \\
& Tinggi & 22 & 19,5 \\
& Total & 113 & 100 \\
\hline Sumber: Data Diolah & &
\end{tabular}

Tabel tersebut dapat menunjukkan bahwa sebagian besar $(67,3 \%)$ memiliki skor hasil belajar yang termasuk dalam kategori sedang. Sedangkan yang berada dalam kategori tinggi sebesar $19,5 \%$ dan yang berada dalam kategori rendah sebanyak 13,3\%. Persentase perolehan skor hasil belajar dapat dilihat dalam gambar berikut ini;

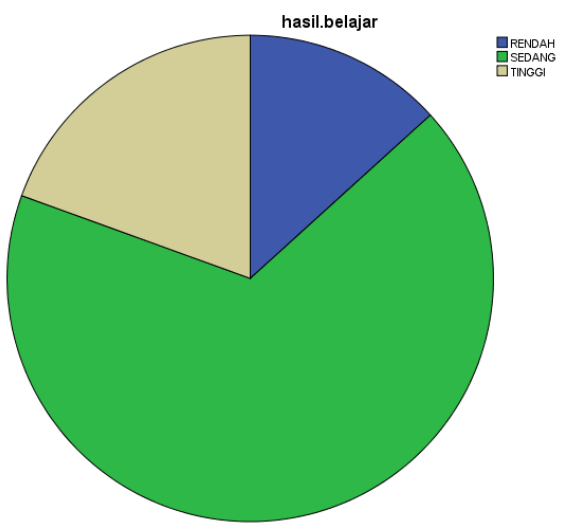

\section{Gambar Kategorisasi Perolehan Skor Hasil Belajar}

Sumber: Data Diolah
Validitas Angket

Instrument yang diuji validitasnya adalah angket yang terdiri dari tiga puluh pernyataan tentang kecerdasan emosional.Pengujian validitas ini menggunakan korelasi Product Moment dengan bantuan SPSS. Adapun hasil uji validitas dapat dilihat dalam tabel berikut ini;

Tabel 9. Hasil Uji Validitas

\begin{tabular}{llll}
\hline Soal & $\mathbf{R}_{\text {hitung }}$ & Soal & $\mathbf{R}_{\text {hitung }}$ \\
\hline 1 & 0,796 & 16 & 0,340 \\
2 & 0,273 & 17 & 0,370 \\
3 & 0,519 & 18 & 0,269 \\
4 & 0,623 & 19 & 0,707 \\
5 & 0,774 & 20 & 0,550 \\
6 & 0,599 & 21 & 0,620 \\
7 & 0,440 & 22 & 0,454 \\
8 & 0,489 & 23 & 0,672 \\
9 & 0,600 & 24 & 0,267 \\
10 & 0,623 & 25 & 0,364 \\
11 & 0,338 & 26 & 0,291 \\
12 & 0,651 & 27 & 0,248 \\
13 & 0,779 & 28 & 0,587 \\
14 & 0,755 & 29 & 0,307 \\
15 & 0,362 & 30 & 0,199 \\
\hline Sum
\end{tabular}

Sumber: Data Diolah

Kriteria untuk menentukan validitas suatu butir soal ditentukan oleh $\mathrm{r}_{\text {tabel }}$ (0,184).Jika $r_{\text {hitung }}>r_{\text {tabel, }}$ maka butir soal dikatakan valid.Dan jika $r_{\text {hitung }}<r_{\text {tabel}}$, maka butir soal dikatakan tidak valid.

Berdasarkan hasil uji validitas yang terlihat dalam tabel, terlihat bahwa nilai $\mathrm{r}_{\text {hitung }}$ paling kecil sebesar 0,199 sedangkan $\mathrm{r}_{\text {hitung yang paling besar sebesar }}$ 
PROGRESS

Jurnal Pendid ikan, Akuntansi dan Keuangan

Universitas Banten Jaya
Vol 3 No. 1, Februari 2020

E-ISSN 2622-7037 |P-ISSN 2623-0763
0,796.Berdasarkan kriteria validitas maka dari ketigapuluh butir soal dapat dinyatakan valid.

\section{Reliabilitas Angket}

Angket yang diberikan kepada peserta didik sebagai responden bertujuan untuk mengetahui dan menggali respon peserta didik tentang kecerdasan emosional yang terdapat dalam diri peserta didik.Angket yang diberikan dibuat sesuai dengan deskripsi yang terdapat dalam operasionalisasi variabel yang telah dikaji oleh peneliti.Untuk mengukur reliabilitas angket yang telah direposn oleh peserta didik, maka peneliti melakukan uji reliabilitas dengan menggunakan nilai koefisien Cronbcah Alpha.

Sekaran (2015:312) menyatakan bahwa koefisien reliabilitas (alpha) 0,8-1,0 memiliki reliabilitas yang baik sedangkan nilai koefisien yang kurang dari 0,6 memiliki reliabilitas yang kurang baik. Berdasarkan hasil pengujian reliabilitas menggunakan SPSS diperoleh hasil yang dapat dilihat dalam tabel berikut ini;

Tabel 10. Hasil Uji Reliabilitas Cronbach's $\mathrm{N}$ of Items Alpha

Sumber: Data diolah
Berdasarkan hasil analisis uji reliabilitas dalam tabel tersebut dapat dilihat bahwa nilai Cronbach's Alpha sebesar 0,895. Nilai tersebut berada diatas nilai 0,6 dan mendekati 1. Sehingga dapat disimpulkan bahwa angket yang digunakan dalam penelitian ini memiliki koefisien reliabilitas yang baik.

\section{Uji Normalitas Data}

Uji normalitas data yang dilakukan dalam kajian ini bertujuan untuk mengetahui distribusi data dalam penelitian ini berada dalam distribusi normal atau tidak. Berdasarkan hasil uji normalitas data menggunakan SPSS dapat dilihat dalam gambar berikut ini;

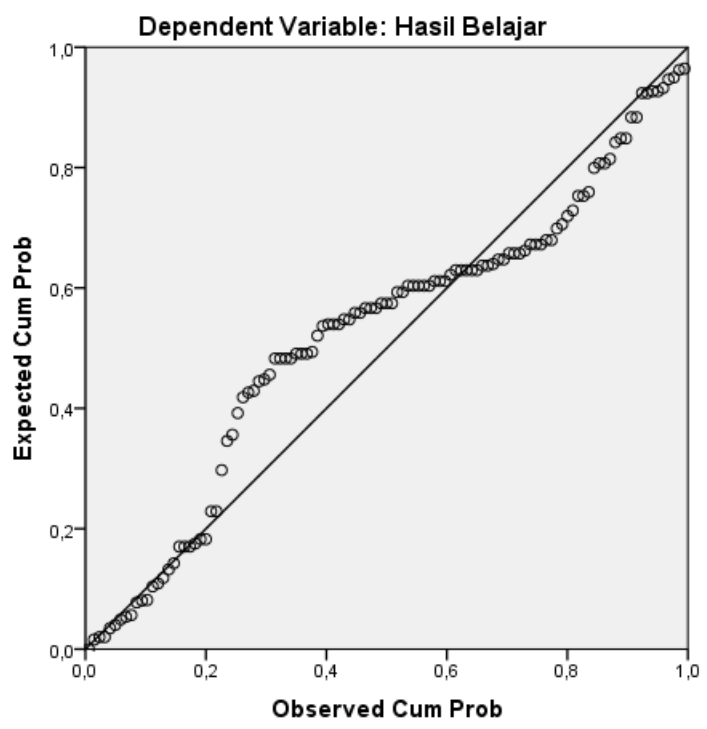

Gambar Hasil Uji Normalitas P-Plot Sumber: Data diolah 
PROGRESS

Jurnal Pendid ikan, Akuntansi dan Keuangan

Universitas Banten Jaya
Vol 3 No. 1, Februari 2020

E-ISSN 2622-7037 |P-ISSN 2623-0763
Uji Hipotesis

Berikut ini disajikan hasil uji korelasi sederhana untuk menguji hipotesis antara variabel kecerdasan emosional dan hasil belajar.

Tabel. 11. Hasil Uji Hipotesis

\begin{tabular}{|c|c|c|c|}
\hline & & $\begin{array}{l}\text { Kecerdasan_ } \\
\text { emosional }\end{array}$ & $\begin{array}{l}\text { Hasil_ } \\
\text { belajar }\end{array}$ \\
\hline \multirow{6}{*}{$\begin{array}{l}\text { Kecerdasan }_{-} \\
\text {emosional }\end{array}$} & Pearson & 1 &, 701 \\
\hline & Correlation & & \\
\hline & Sig. (2-tailed) & &, 000 \\
\hline & $\begin{array}{l}\text { Sum of Squares } \\
\text { and Cross-products }\end{array}$ & 7029,735 & 1758,168 \\
\hline & Covariance & 35,980 & 15,698 \\
\hline & $\mathrm{N}$ & 113 & 113 \\
\hline \multirow[t]{6}{*}{ Hasil_belajar } & Pearson & $701^{* * *}$ & 1 \\
\hline & Correlation & & \\
\hline & Sig. (2-tailed) & ,000 & \\
\hline & $\begin{array}{l}\text { Sum of Squares } \\
\text { and Cross-products }\end{array}$ & 1758,168 & 1562,460 \\
\hline & Covariance & 15,698 & 13,951 \\
\hline & $\mathrm{N}$ & 113 & 113 \\
\hline
\end{tabular}

Sumber: Data diolah

Berdasarkan tabel tersebut, terlihat bahwa nilai koefisien untuk $r_{\text {hitung }}$ sebesar 0,701 . Adapun kriteria penerimaan hipotesis (taraf signifikansi 5\%) dalam kajian ini yakni;

1. $\mathrm{H}_{\mathrm{o}}$ ditolak jika $\mathrm{r}_{\text {hitung }}>\mathrm{r}_{\text {tabel }}$

2. $\mathrm{H}_{\mathrm{o}}$ diterima jika $\mathrm{r}_{\text {hitung }}<\mathrm{r}_{\text {tabel }}$

Sehingga berdasarkan hasil uji hipotesis menggunakan korelasi Pearson nilai $r_{\text {hitung }}$ $(0,701)>r_{\text {tabel }}(0,184)$ maka $H_{o}$ ditolak dan dapat diambil kesimpulan bahwa kecerdasan emosional memiliki pengaruh yang positif terhadap hasil belajar.

\section{SIMPULAN DAN SARAN}

Simpulan

Berdasarkan hasil penelitian dan pembahasan, kesimpulan dalam kajian ini diantaranya;

1. Tingkat kecerdasan emosional peserta didik jurusan Akuntansi di SMK Negeri

1 Ciruas berada dalam rentang sedang yakni $44,2 \%$.

2. Hasil belajar peserta didik jurusan Akuntansi di SMK Negeri 1 Ciruas berada dalam kategori sedang yakni $67,3 \%$.

3. Terdapat hubungan yang positif antara kecerdasan emosional terhadap hasil belajar. Hal ini berdasarkan hasil pengujian data yang menunjukkan bahwa $r_{\text {hitung }}(0,701)>r_{\text {tabel }}(0,184)$.

Saran

Berdasarkan hasil penelitian terdapat saran dalam kajian ini, yakni bahwa sekolah dan guru sebagai pendidik yang memiliki waktu serta frekuensi interaksi yang intensif dengan peserta didik dapat mengembangkan berbagai program yang bertujuan tidak hanya untuk mengembangkan kecerdasan intelektual namun juga mengembangkan program untuk mengembangkan kecerdasan emosional karena hal tersebut dapat 
berpengaruh terhadap pencapaian hasil

belajar peserta didik.

\section{DAFTAR PUSTAKA}

Goleman, Daniel. (2018). Emotional Intelligence. Jakarta: Gramedia Pustaka Utama.

Syah, Muhibbin. (2018). Psikologi Pendidikan. Bandung: Remaja Rosdakarya.

Chandra, Giovvani. (2010). Panduan Pendampingan Kecerdasan Emosional. Mojokerto: Manuskrip.

Toyyibah, Ibay. (2017). Cara Belajar Gue Banget. Jakarta: Elex Media Komputindo.

Suprijono, Agus. (2017). Cooperative Learning. Yogyakarta: Pustaka Pelajar.

Sekaran, Uma. (2015). Metodologi Penelitian Bisnis.Ed 4 Buku 1. Jakarta: Salemba Empat. 